\title{
A Review on the Trends and Ethical Issues of Labour Migration from Asia and the Pacific
}

\author{
Dorji Wangchuk $^{1}$, Wanchai Dhammasaccakarn ${ }^{2}$, Yenten Jamtsho ${ }^{1}$ \& Kelzang Dorji ${ }^{1}$ \\ ${ }^{1}$ Jampeling Higher Secondary School, Kanglung, Trashigang, Ministry of Education, Bhutan \\ ${ }^{2}$ Faculty of Liberal Arts, Prince of Songkla University, Hat Yai, Songkhla, Thailand \\ Correspondence: Dorji Wangchuk, Jampeling Higher Secondary School, Kanglung, Trashigang, Ministry of \\ Education, Bhutan. E-mail: dwzamin@gmail.com
}

\author{
Received: August 21, 2014 Accepted: September 1, $2014 \quad$ Online Published: October 30, 2014 \\ doi:10.5539/ass.v10n21p186 URL: http://dx.doi.org/10.5539/ass.v10n21p186
}

\begin{abstract}
Labour migration is a phenomenon, which is not motionless; rather, it amplifies rapidly particularly from superfluous labourer countries to the labourer scarce countries. In the midst of trade liberalization and globalization reshaping the world's economy in toto, the labour migration has multiplied additionally. Labour migration has benefited both the sender and recipient countries. Most significantly, the remittances sent by migrants from overseas have contributed to the economic development of their countries of origin and the living standards of their families have improved progressively. Conversely, the increase in labour migration has founded numerous social problems that have threatened the safety of the migrants and their families back at home. Consequently, an instantaneous need has arisen for both sender and recipient countries to act collaboratively in formulating policies regarding the migrants' intrinsic needs and therefore ensuring the sustainability of labour migration in the future.
\end{abstract}

Keywords: Asia, globalization, labour, migration, Pacific, remittances

\section{Introduction}

The migration of labourers traces its history from the periods of colonialism (Wells, 1996; Kaur, 2009 ; cf. Baba, 2013). Therefore, labour migration diaspora is not a contemporary phenomenon; rather, it is an evolving activity occurring in both developed and developing nations around the globe (Massey, et al., 1993; Wickarmasekara, 2000; Tapinos, 2002; Korobkov \& Zainochkovskaia, 2004). Wells (1996) pointed out that the slave migration from Africa to the Americas was in fact the largest illustration of human migration in the annals of the migration history. Approximately 15 million Africans were taken to the Americas as slave workers (Wells, 1996). Migration was also a common feature in Europe during the period of industrialization; migrants were in search of jobs, leaving behind the agricultural activities (Wells, 1996). The labour migration has further amplified as a result of globalization, by then better means of communication and technologies helped people to acquire ample information from abroad regarding job opportunities and wages (Wickarmasekara, 2000; Linard, 1998; Taran \& Geronimi, 2002; Tapinos, 2002; Chaudhuri \& Yabuuchi, 2007; Wang, et al., 2011; Betran \& Pons, 2011; Athukorala, 2012; Promsaka Na Sakolnakorn et al., 2013). The World Bank (2011) estimated that there were more than 215 million international migrants in the world by the end of 2010 , and the number is expected to increase in the future. In addition, the ILO Press release (2012) has estimated 21 million people are trafficked as forced labour.

Labour migration trends emerged in the Middle East in the 1970s with the sudden rise in the price of oil and massive construction works that began in between 1970s and 1980s, bringing workers from abroad who were in sought of the better wages (Choucri, 1978; Wells, 1996; Edwards, 2005; Kaur, 2010). Towards the end of the 1970s, many workers from Asian countries like India, Pakistan, Bangladesh, Sri Lanka, and Southeast Asian countries of the Philippines, Thailand, and Korea began to migrate into the Middle East (Wells, 1996; Kaur, 2010). In the 1990s, Thais and Filipinos became expensive and were replaced by much cheaper workers from China (Wells, 1996). However, Wells (1996) stated that towards the end of the 1980s, oil prices in the Middle East dropped; ultimately affecting the wages of the foreign workers (see Edwards, 2005). The situation was further worsened by the Gulf Crisis of 1990, in which about two million Arab labourers lost their jobs in the Middle East (Fergany, 2001; Shah, 2007). Because migrating is expensive, migrants would be willing to come to 
countries that offered better wages (Wells, 1996; Kesztenbaum, 2008). By the late $19^{\text {th }}$ and early $20^{\text {th }}$ centuries, many Indian and Chinese labourers migrated to Southeast Asia, one of the main destinations for workers, and an indication of Asian globalization (Wells, 1996; Kaur, 2009; Kaur, 2010).

Today, most of the Asian countries are growing economically independent; and therefore, the demand for workers is also increasing in the continuum (Taran \& Geronimi, 2002). Asia is also considered as one of the fastest economically growing regions in the world since the 1970s (Wickarmasekara, 2000; Kim, 2012; Lee and Francisco, 2012). Consequently, tremendous modification has occurred in the patterns of migration, with most Southeast Asians migrating within Southeast Asian countries, with a few exceptions in the case of South Asian workers still migrating to the Middle East (Wickarmasekara, 2000; United Nations Regional Task Force, 2008, p. 8; Kaur, 2010). Labour migration further expanded in the 1970s and 1980s after a dramatic fall in oil prices in the Middle East (Kaur, 2010).

According to the common conversation concluded by Asian Migration Centre (AMC), Asian Domestic Workers Union (ADWU), Forum of Filipino Reintegration and Savings Groups (FFRSG), Indonesian Migrants Workers Union (IMWU), and Thai Women Association (TWA, 2001, p. 14), Asian migrants approximate to 15 million worldwide, 10 million of which work in the Middle East, Japan, Korea, Taiwan, Hong Kong, Malaysia, and Singapore. The Asia Migration Yearbook (AMC \& AFA, 2005, p. 31) states that Bangladesh has sent about 4,885,704 migrants to the destination countries Saudi Arabia, UAE, Kuwait, Malaysia, India, and South Korea; Burma has 921,492 people working in Thailand, South Korea, Malaysia, and Singapore; Cambodia has deployed 1,83,817 workers to Thailand, Malaysia, Saudi Arabia, and a few in South Korea; China has 175 million working overseas; India has deployed 549,000; and Indonesia has deployed 1,736,717 workers overseas. About 264,663 workers were sent to work in Malaysia and about 18,923 to Singapore; Laos received 179,887; Malaysia, 2.6 million, of which Nepalese comprise the second largest migrant group (70,000); in Nepal, 182,141 labour migrants went abroad, but $77 \%$ of its total migrants go to India; the Philippines deployed $1,062,567$ to 197 destination countries; Sri Lanka sent 136,998 overseas; Thailand sent 139,667; and Vietnam sent 70,000. The immigration and emigration figures of all these countries have altered over time. For instance, the number of Thailand migrants working overseas was 139,667 in 2005, but by 2010 the figure had increased to143, 795 (McDougall et al., 2011). Hong Kong imported 223,200 workers, mostly from the Philippines and Indonesia. Japan had attracted 2,011,555 foreign workers by 2005, and of the total number, South Koreans comprised the largest group $(598,687)$.

However, statistically the numbers of Korean workers in Japan have declined since 1945 (AMC \& AFA, 2005, p. 37). At the same time, the numbers of China and Brazil workers (it means workers from China and Brazil migrating to Japan) have been gradually increasing to 519,561 (China) and 302,080 (Brazil). South Korea has employed 358,167 labourers, and the number rose to 1,188,000 in 2008 (Kwon \& Chun, 2011); Taiwan has employed 327,396; and Singapore has employed 575,000, of which 150,000 were female (AMC \& AFA, 2005, p. 24). Recently, the ruling government in Bhutan has decided to deploy approximately 30,000 Bhutanese to work in oversea countries like the Middle East to curb unemployment related issues. This clearly states that the mighty Himalayan country like Bhutan has very well understood the cumulative benefits of sending people abroad for the work.

The literatures on the labour migration had concluded that the migration has benefited both source and the recipient countries (Wells, 1996; Athukorala, 1992; Wickarmasekara, 2000; Kaur, 2010; Battistella \& Binodkhadria, 2011; Promsaka Na Sakolnakorn et al., 2013). Most significantly, the remittances sent back home by the migrant labourers working abroad from their original homeland have facilitated to improving the living standards of their respective family members, educating the children, debt defrayal, and also the remittances have helped to plummeting the cost of borrowing remarkably in the arena of international capital market (Athukorala, 1992; Jones \& Pardthaisong, 1999; Sorensen et al., 2002; Glytsos, 2002; AMC \& AFA, 2005, p. 56; Ghosh, 2006; Skeldon, 2008a; Jampaklay \& Kittisuksathit, 2009, p. 1; Yoeh et al., 2010; Agbola \& Acupan, 2010; Promsaka Na Sakolnakorn et al., 2013). Additionally, the literatures also mention that the remittance has the potentiality to minimizing the poverty in the respective country (Richard et al., 2005; Skeldon, 2008a; Promsaka Na Sakolnakorn et al., 2013).

However, some researchers have argued that the remittance can also lead to inequality (e.g., Russel1, 1986; Jones, 1998b; Mutersbaugh, 2002; Skeldon, 2008a): poor people are unable to make use of this method for earning income because they cannot pay for entry into the destination countries. Yoeh and colleagues (2010) also stated that the departure of migrants has an adverse impact on family members, particularly in the role of the husband in looking after family matters falling to the wife (see Hugo, 2002). The ILO $(2008$, p. 8$)$ has stated that every year migrant labourers send remittances back to their home country amounting to 
approximately USD 73 billion (Wickarmasekara, 2000). The World Bank (2010, p. 5) has calculated that developing countries received an estimated remittance of USD 325 billion, a six per cent increase from 2009, and worldwide remittance was calculated to be USD 440 billion. The beneficiaries of the remittance are primarily Asian countries (ILO, 2008, p. 12). Aside from remittance benefits, migrants also put into practice those skills acquired from the destination countries, eventually benefiting the countries of origin (Skeldon, 2008a).

\section{Purpose of Migration: Why do People Migrate?}

There are, in fact, numerous reasons and purposes for migrating; however, it is crucially significant to know and understand that, people migrate not solely for self-benefit only but also for the benefit for their country of origin and the families (IOM, 2013, p. 31).

\subsection{Better Income Source: A Desire for Higher Wages}

It is very imprudent to generalize the reasons for migration, because all migrants have their own purposes for migrating, both economic and non-economic (Wickarmasekara, 2000). Nonetheless, most researchers believe that the principal reason associated to labour migration to the oversea destination countries is due to the better wages that they are paid comparing to their countries of origin, and this enable them to send supplementary money to their families and help them to improve their living standards and the defrayal of the debts (Athukorala, 1992; Griffin, 1998 cited in Wickarmasekara, 2000; Jones \& Pardthaisong, 1999; Manning, 2002; Baka \& Laeheem, 2006; Skeldon, 2008a; Yoeh et al., 2010; Promsaka Na Sakolnakorn et al., 2013). The best example comes from the Middle East's situation in the mid-1980s when oil prices dropped abruptly, and the region lost many of its foreign migrants because the Gulf nations could no longer provide them with better wages (Wells, 1996). For instance, in Bahrain the wages of construction labourers decreased by $30 \%$ in 1989 (Wells, 1996). In the beginning of the 1970s, many Asian countries viewed the Gulf countries as a home for earning better income (Edwards, 2005; Kaur, 2010). Therefore, the Asian nations of India, Sri Lanka, Bangladesh, Pakistan, Nepal, China, Thailand, the Philippines, and Indonesia began to deploy workers, knowing the economic benefits they would obtain from the Middle East (Kaur, 2010).

\subsection{Shortage of Labour Force in the Destination Countries}

Shortage of labourers is the primary reason for the migration diaspora (Wickarmasekara, 2000; Manning, 2002; Sorensen et al., 2002; Kaur, 2010). Most economically developed and developing countries face the problem of domestic worker shortages (Wickarmasekara, 2000; Sorensen et al., 2002; Kaur, 2009; Kaneko, 2009; Kwon \& Chun, 2011). Such problems were encountered by Middle East countries in the 1970s and also by Southeast Asian countries like Singapore, Brunei, Japan, Taiwan, and Malaysia (Wells, 1996; Edwards, 2005; Kaneko, 2009; Kaur, 2010; Kwon \& Chun, 2011). These nations had to depend on those countries having an adequate number of workers to meet the demand. For instance, as South Korea grew stronger economically, it also demanded a surplus of labourers to achieve the required numbers to work in the country's industries. Eventually, South Korea had to import workers from overseas. Foreign workers in South Korea rose to 1,188,000 in 2008 from a figure of 308,000 in 1960s (Kwon and Chun, 2011). Similarly, Japan and Taiwan are also facing a labour shortage problem due to their aging population and low fertility rate (Yamanaka, 2003 as cited in Kaneko, 2009). India and China remained enormous suppliers of labourers because they had the largest populations in the world prior to 1940 (Kaur, 2009).

\subsection{Unemployment in the Countries of Origin}

The issue of labour migration diaspora traces close correlation with unemployment of the particular country of origin (Wickarmasekara, 2000; Manning, 2002; Sorensen et al., 2002; Kaur, 2010; Agbola \& Acupan, 2010; Promsaka Na Sakolnakorn et al., 2013). According to Promsaka Na Sakolnakorn et al., (2013) the economic crisis was a pivotal factor that created unemployment issues in the Southeast Asian nations. The Southeast Asian nations implemented various strategies to overcome the economic crisis and the unemployment problem and they were indeed very successful (Wickarmasekara, 2000; Kaur, 2009; Promsaka Na Sakolnakorn et al., 2013). Eventually countries like Singapore, Malaysia, Brunei, and Thailand were successful in combating the unemployment problem resulted in by the economic crisis; however, remaining Southeast Asian countries are still working for better solutions to halt the unemployment crisis (Wickarmasekara, 2000; Kaur, 2009; Promsaka Na Sakolnakorn et al., 2013). Similarly, nations like Indonesia, the Philippines, and Bangladesh also adopted the policies and their immediate solution was to send their people to work abroad (Kaur, 2009; Agbola \& Acupan, 2010; Promsaka Na Sakolnakorn et al., 2013). 
Initially the Philippines deployed its labourers in the name of the country's economic development; however, a few scholars later argued that the deployment of workers overseas by the Philippines was a strategy to ease unemployment problems rather than a development policy (Lindio-McGovern, 2004; O'Neil, 2004; Yang, 2004, cited in Agbola \& Acupan, 2010). Indonesia even included the agenda of sending workers abroad in its five-year plan to gain relief from the domestic unemployment issue. Thailand proposed to send 250,000 workers away home for similar reasons (Wickarmasekara, 2000). Liberalization of trade as a result of globalization has also shown a great impact on easing unemployment rates (Manning, 2002; Hasan et al., 2012; Dawson, 2013). The escalating unemployment rate (7\%-12\%) in Bhutan has compelled her to look for alternatives. Bhutan is now sending her people for work in Thailand and the Middle East.

\subsection{Remittances and Its Cumulative Benefits}

The cumulative benefits of remittances and the remittances itself have gained an utmost popularity amongst the labourers, policy makers, financial institutions, academics and the migrants association (De Bruyn \& Wets, 2006, p. 1). The remittances sent back home by overseas migrants is the final fruit cultivated through the hardship they experience in the destination countries (Athukorala, 1992; Wells, 1996; Ilahi \& Jafarey, 1999; Wickarmasekara, 2000; Richard et al., 2005; Hull, 2007; Martin, et al., 2007, p. 2; Skeldon, 2008a; Kaur, 2010; Yoeh et al., 2010; Battistella \& Binodkhadria, 2011). Eventually, the people in the countries receiving remittance benefit greatly from it, although this income might not be channeled properly and might result in inequality (Jones, 1998a; Jones, 1998b; Mutersbaugh, 2002; Hull, 2007; Skeldon, 2008a; Skeldon, 2008b). Remittance is also considered a means to the growth and development of the nation's economy (Massey et al., 1993; Hull, 2007). Consequently, in the past few decades many developing nations have paid massive attention to gaining remittances by deploying workers overseas (Blackwell \& Seddon, 2004, cited in Agbola \& Acupan, 2010). Blackwell and Seddon (2004) also viewed remittances as a potential factor to bring down the poverty of the origin nations (see Agbola \& Acupan, 2010).

\subsection{Regional Co-operation: An Example from the Southeast Nations}

Trade unions also help promote labour migration and ensure migrants' safety while working abroad (Wells, 1996; Wickarmasekara, 2000). However, according to Wickarmasekara (2000), the formation of these unions was prohibited in the Middle East. Although trade unions have been stronger in Asian nations and have thus promoted the movement and safety of migrant labourers, the economic crisis has made them weaker (Wickarmasekara, 2000). In addition, trade unions in South Korea, the Philippines, and Pakistan have proven to be effective and efficient in maintaining safety and promoting labour migration overseas (Wickarmasekara, 2000).

The decolonization of communist and socialist regimes and the end of the Cold War eventually lead to the formation of Association of South East Asian Nations ASEAN, which brought Southeast Asian nations together for economic development (Kaur, 2009). Under the umbrella of ASEAN, free trade links were ventured through the anticipation of the ASEAN Free Trade Area (AFTA), and large numbers of the ASEAN nations' workers began migrating within the region (Kaur, 2009). The flow of labour migration was enhanced further with the establishment of the ASEAN Framework Agreement on Service (AFAS), which helped develop Southeast Asia as an economic community (ibid). As a labour-importing country, Taiwan has created policies to recruit workers from ASEAN nations for both political and economic reasons. Because most of its workers come from ASEAN nations, Taiwan wants them to remain sustainable labourer suppliers in the future and works to maintain a rigorous friendship with them (Kaneko, 2009).

\subsection{Factors Facilitating Migration Diasporas}

International labour migration also depends on factors like the information technology (IT) communication, high-tech, better transportation, and media (Reitz, 2001; Favell, 2008; Teitelbaum, 2008; Ciarniene \& Kumpikaite, 2011; Remennick, 2013). Doomernik (2013) considers them as push and pull factors. These facilitating factors make migration possible and comfortable (Collins, 1999; Sorensen et al., 2002). The progress in communication area has improved the mode of information transfer (Promsaka Na Sakolnakorn et al., 2013). As a result, the relatives living abroad were able to send information to the county of origin regarding the availability of jobs and other mandatory procedures, thereby fostering labour migration (Wickarmasekara, 2000; Collins, 1999; Yoeh et al., 2010; Wickarmasekara, 2000; Kaur, 2009; Promsaka Na Sakolnakorn et al., 2013). Furthermore, developments in communication and technology have brought countries closer and eventually liberalized trade (Collins, 1999). Global commerce has also resulted in the signing of economic treaties between nations for free trade, which in return has had a great impact in terms of labourers migrating freely (Weinberg, 2001). 


\section{Economic Advantages of the Migration}

The tradition of labour migration has greatly benefited both sender and the receiver countries; however, the fact is that most of recipient countries do not mention the positive impact of the migrants (Jones, 1998a; Jones, 1998b; Jones \& Pardthaisong, 1999; Wickarmasekara, 2000; Mutersbaugh, 2002). The jobs that are being neglected are being performed by migrants from abroad, and therefore, the benefits of labour migration should not be viewed from one perspective. In fact, labour migration shows benefits from both angles (Wickarmasekara, 2000; Ghosh, 2006; Glytsos, 2002). Labour migration is indeed a great boon to th os e countries facing the problem of unemployment, like the Philippines and Thailand, and also to those countries experiencing labour shortages, like Singapore, South Korea, and Brunei (Wickarmasekara, 2000; Kaur, 2009; Kaur, 2010; Agbola \& Acupan, 2010).

Remittance is an economic relieve for both migrants and their countries of origin (Russell, 1986; Massey, 1988; Athukorala, 1992; Durand et al., 1996; Wells, 1996; Ilahi \& Jafarey, 1999; Wickarmasekara, 2000; Richard et al., 2005; Hull, 2007; Skeldon, 2008a; Blen, 2009; Kaur, 2010; Yoeh et al., 2010; Battistella \& Binodkhadria, 2011). Labour migration increases every year, and it will speed up in the future (Weinberg, 2001). Therefore, remittances will also increase as more migrants travel overseas, benefiting both the families of migrants and the development of their home countries (Weinberg, 2001; De Haas, 2005; Hull, 2007; Yoeh et al., 2010).

\section{Social Impacts of Labour Migration}

Many destination countries have begun to experience the pressure of hostility and violence in the $21^{\text {st }}$ century as a result of labour migration of varied cultures, ethnicities, languages, and races (Wickarmasekara, 2000; Docquier \& Rapoport, 2003; De Haas, 2005; Kaneko, 2009; Lenard, 2012; Baba, 2013; León, 2013). Discrimination can have significant repercussions on destination countries because chances are very high that foreign workers may not want to work in such an environment (Lowell et al., 1995). For instance, in Taiwan many foreign workers are facing numerous social issues such as mistreatment, physical and psycho-physical abuses, late payments, discrimination, and improper and unsafe working environments (AMC, ADWU, FFRSG, IMWU, \& TWA, 2001, pp. 35-41; Cheng, 2003; Yiu, 2003; Loveband, 2004; Yiu, 2005; Huang \& Loa, 2009 as cited in Kaneko, 2009).

The crime resulted from labour migration is also a great concern for recipient countries (Hui, 1997; Wickarmasekara, 2000; Kaneko, 2009; Yoeh et al., 2010). Hui (1997) stated that foreign labourers are more likely to be involved in various crimes, which can lead to misunderstandings between the sender and the recipient countries (see Wickarmasekara, 2000; Kaneko, 2009).

The 'crisis of care' or the 'care drain' (Parrenas, 2005, as cited in Hoang et al., 2012) has become a recent social concern as a corollary of more female workers migrating to earn a more substantial income (Wickarmasekara, 2000; Bras, 2003; Hoang et al., 2012). Many children are left unattended by their mothers, and the responsibility for their care shifts to other members of the family (Hoang et al., 2012). This issue is very common in the Philippines, and children feel uncomfortable with their father after he returns home because of the prolonged gap between the parents and the children (Yoeh et al., 2010). Furthermore, the children left behind develop the tendency to lose faith, love, care, and respect for parents' away home for longer periods of time (Moran-Taylor, 2008a as cited in Yoeh et al., 2010). Studies carried out in the Philippines, Sri Lanka, and China revealed that children are likely to change their behaviour and at the same time can adjust to their surroundings even though their parents are apart from them (Yoeh et al., 2010). Some researchers, like Xiang (2007) and Battistella and Conaco (1998), found that children are also likely to build up negative behaviours (see Yoeh et al., 2010).

Meanwhile, the rapid increase in female migration has posed risks of spreading sexually transmitted diseases because many women are sexually harassed or sexually exploited (Wickarmasekara, 2000; Kaneko, 2009). Foreign migration in Japan during the 1980s was mainly composed of females from the Philippines and Thailand who were involved in sex work (Kaneko, 2009).

\section{Trafficking and Its Instantaneous Measures}

Trafficking is categorized as one of the dark parts of the globalization by Cho et al., (2013). It is a growing concern to sender and the recipient countries, and more importantly to the International Labour Organization. Human trafficking is also considered as the forced labour (ILO, 2005, p. 6; ILO, 2012, p. 13). In 2005, Belser et al., (2005, p. 8; ILO, 2012, p. 11) recorded 12.3 million people were trafficked as forced labour, and 2.45 million people were trafficked in person (20\%). Asia and the Pacific were the leading forced labour traffickers (Belser et al., 2005, p. 9). In addition, the recent ILO Press release (2012) has estimated forced labour up to 21 million people with the probability of three people from every 1000 being trapped as force labour (Table 1). The rate of 
trafficking has escalated by $26.1 \%$ ( $\mathrm{n}=8.7$ million) between 2005 and 2012. ILO (2012) has identified that 4.5 million $(24.1 \%)$ of the trafficked labourers were sexually exploited and 14.2 million $(75.9 \%)$ were forced to work in the areas like agriculture, construction and domestic chores (Table 2).

The number of trafficking might increase alarmingly if instantaneous measures are not in place. A collaborative policy among labour sender countries, labour recipient countries and international organization such as ILO is deemed essential. In addition, collective measures also must be taken in order to curtail those illegal dealers of labour traffickers.

Table 1. Region wise bifurcation of forced labour

\begin{tabular}{lll}
\hline Regions & Number in Million & Percentage \\
\hline Asia-Pacific & 13.3 & 63 \\
Africa & 3.7 & 18 \\
Latin America & 1.8 & 9 \\
Middle East & 0.6 & 3 \\
North America & 1.5 & 7 \\
\hline
\end{tabular}

Source: ILO Press release, 2012

Table 2. Number of forced labour by job specification

\begin{tabular}{lll}
\hline Forced Labour in Million & Percentage & Job Specifications \\
\hline 14.2 & 75.9 & Agriculture, Construction and Domestic Chores \\
4.5 & 24.1 & Sexual Exploitation \\
Total: 18.7 & 100 & \\
\hline
\end{tabular}

Source: ILO Press release, 2012

\section{Discussion}

Manpower is indispensable for the economic development, and it has been necessary since the period of colonialism and industrialization (Wells, 1996; Hui, 1997; Kaur, 2009). For instance, Malaysia is a traditional labour supplier to Singapore, and now it has developed economically, creating better opportunities for Malaysians living in Singapore and abroad. Because Singapore is very expensive to live in, there is a growing chance that Malaysians and other migrants might leave Singapore for Malaysia in the future, eventually depriving Singapore of manpower (Wells, 1996; Hui, 1997). Therefore, a better solution is required to attract foreign workers, especially in countries with labourer shortage problem like Japan, Brunei, and Taiwan (Wells, 1996; Hui, 1997; Wickarmasekara, 2000; Kaneko, 2009).

In the annals of labour and migration histories, Asian countries have remained major origins of labourers to different countries in the world (Wells, 1996; Wickarmasekara, 2000; Kur, 2010; Yoeh et al., 2010). India, Pakistan, Bangladesh, and Sri Lanka were particularly popular in supplying labour, especially to the Middle East, accompanied by countries in Southeast Asia: the Philippines, Malaysia, Thailand, South Korea, and China (Wells, 1996; Wickarmasekara, 2000; Kaur, 2009; Kaur, 2010; Agbola \& Acupan, 2010). With rapid economic progress in Asia, most profoundly seen in Southeast Asia, labour migration patterns have altered a great deal in a few decades (Wickarmasekara, 2000; Docquier \& Rapoport, 2003; Kaur, 2009; Kaur, 2010; Agbola \& Acupan, 2010; Hoang et al., 2012; Kim, 2012).

Illegal migration has been on the rise since labour-migration culture began and the issue still increases today (Wells, 1996; Wickarmasekara, 2000; Manning, 2002; Kaur, 2009). In addition, human trafficking is also growing (Wickarmasekara, 2000; Manning, 2002; Mahmoud \& Trebesch, 2010). It is estimated in the studies of Mahmoud and Trebesch (2010) that about 12 million people are categorized as forced labourers, and almost half of them resulted from human trafficking (ILO, 2005 as cited in Mahmoud \& Trebesch, 2010). Recently, ILO estimated that 21 million human were trafficked in 2012. Therefore, the governments of different countries in Asia have designed their own migration policies since the 1980s (Wickarmasekara, 2000; Manning, 2002; Yoeh et al., 2010). Some policies are very strict to control illegal migrants, like those of Singapore, Hong Kong, and Taiwan, while countries like Japan, South Korea, Malaysia, and Thailand have had poor laws that were unable to control the massive flow of migrants both skilled and unskilled (Manning, 2002). Since labour migration has become essential to the region's economic development, it is critical to create better policies that guarantee 
migrants' safety both at home and away from home (Wickarmasekara, 2000; Yoeh et al., 2010). Furthermore, Mahmoud and Trebesch (2010) suggested that illegal migration and human trafficking might be reduced through proper awareness campaigns. However, according the ILO (2012), Asia and the Pacific countries remain as the leading trafficking zone (see Table 1).

Problems related to migration are of significant concerns in the pace of economic development, particularly in the labour-dependent countries (Wells, 1996; Wickarmasekara, 2000; Kaneko, 2009; Mahmoud \& Trebesch, 2010). Discrimination and harassment of foreign labourers are on the rise (Wickarmasekara, 2000; Docquier \& Rapoport, 2003; Cheng, 2003; Yiu, 2003; Loveband, 2004; De Haas, 2005; Lowell et al., 1995; Kaneko, 2009). Therefore, all countries importing foreign labourers must ensure that policies are in place to protect the safety and human rights of those workers residing in their land and rendering services.

\section{Conclusions}

This paper has focused on labour migration in Asia with special emphasis on Southeast Asia and the Pacific. The sudden downfall in the price of oil in the Middle East and the rapid economic development of Southeast Asia changed the labour migration route in the late 1970s, and further in the 1980s. Since then, economically developing nations of the Far East like South Korea, Singapore, Japan, Brunei, and Malaysia have imported labourers from outside due to labour shortages and their countrymen's unwillingness to work.

Various trends in migration have escalated in the past few decades, and many different researchers have studied the migration trends. Illegal migration is rising along with human trafficking. Both labour receiver and sender countries must create policies to combat such issues. However, little success has been shown. Very recently, the feminization of migration has played a leading role in posing further tensions, because many migrant women are involved in the sex business or have experienced harassment. Because of this, rates of sexually transmitted diseases have drastically increased. In addition, the increase in female migrants going overseas for work has had repercussions back home: the 'crisis of care' or 'care drain'.

Many researchers support labour migration although it is associated with numerous social and ethical issues, and yet these issues are of greatest concern to the world organizations such as International Labour Organization. The worthy benefit noticed by most of the migrants is the remittance. Migrants and their country of origination believe that the remittance can solve many problems like meeting the educational needs of the children, providing better shelter for the family, purchasing daily required goods and most importantly the migrant's family can defray the debts they owe to others. In addition, remittances are considered as one of the means to eradicating poverty to a certain level though most of the researchers have argued with this avowal stating that it might result in the inequality among the people. The most beneficiary outcome of the remittances is the enhancement of economic advancement. The countries with surplus manpower take this privilege and send their people abroad for the work and solve various problems of the home country. The Philippines is one such nation.

\section{References}

Agbola, F. W., \& Acupan, A. B. (2010). An empirical analysis of international labour migration in the Philippines. Economic Systems, 34(4), 386-396. http://dx.doi.org/10.1016/j.ecosys.2010.03.002

AMC \& AFA (2005). Asia migration yearbook: Thematic reports. Bangkok: Asian Migrants Centre.

AMC, ADWU, FFRSG, IMWU, \& TWA (2001). Baseline research on racial and gender discrimination towardss Filipino, Indonesian and Thai domestic helpers in Hong Kong. February, 2001: Hong Kong SAR Government.

Athukorala, P. C. (1992). The use of migrant remittance in development: Lessons from the Asian experience. Journal of International Development, 4(5), 511-529. http://dx.doi.org/10.1002/jid.3380040504

Athukorala, P. C. (2012). Asian trade flows: Trends, patterns and prospects. Japan and the World Economy, 24(2), 150-162. http://dx.doi.org/10.1002/jid.3380040504

Baba, M. L. (2013). Anthropology and Transnational Migration: A Focus on Policy. International Migration, 15(2), 1-9. http://dx.doi.org/10.1111/imig.12083

Battistella, G., \& Binohkhadria. (2011). Labour migration in Asia and the role of Bilateral migration agreements: Market access facilitation by informal means. Market for Migration and Development (M4MD): Trade and Labour Mobility Linkages-Prospects for Development, 13-15 September, Bern.

Battistella, G., \& Conaco, M. C. (1998). Impact of labour migration on the children left behind: Philippine study. Sojourn, 13(2), 220-241. 
Betran, C., \& Pons, M. A. (2011). Labour market response to globalization: Spain, 1880-1913. Explorations in Economic History, 48(2), 169-188.

Blackwell, M., \& Seddon, D. (2004). Informal remittances from the UK: Values flows and mechanisms. Norwich: UK Department for International Development.

Bras, H. (2003). Maids to the city: migration patterns of female domestic servants from the province of Zeeland, the Netherlands (1850-1950). The History of Family, 8(2), 217-246. http://dx.doi.org/10.1016/ S1081-602X(03)00027-7

Chaudhuri, S., \& Yabuuchi, S. (2007). International migration of labour and skilled-unskilled wage inequality in a developing economy. Economy Modelling, 24(1), 128-137. http://dx.doi.org/10.1016/j.econmod. 2006.06.006

Cheng, S. J. A. (2003). Rethinking the globalization of domestic service: Foreign domestics, state control, and the politics of identity in Taiwan. Gender and Society, 17(2), 166-186. http://dx.doi.org/10.1177/ 0891243202250717

Cho, S. Y., Dreher, A., \& Neumayer, E. (2013). Does Legalized Prostitution Increase Human Trafficking? World Development, 4l(1), 67-82. http://dx.doi.org/10.1016/j.worlddev. 2012.05 .023

Choucri, N. (1978). Migration processes among developing countries: The Middle East. Migration and Development Study Group, Centre for International Studies, Cambridge, Massachusetts 02139: Massachusetts Institute of Technology.

Ciarniene, R., \& Kumpikaite, V. (2011). International Labour Migration: Students Viewpoint. Inzinerine Ekonomika-Engineering Economics, 22(5), 527-533. http://dx.doi.org/10.5755/j01.ee.22.5.971

Collins, W. J. (1999). Labour mobility, market integration, and wage convergence in late $19^{\text {th }}$-century India. Explorations in Economic History, 36(3), 246-277. http://dx.doi.org/10.1006/exeh.1999.0718

De Haas, H. (2005). International migration, remittances and development: Myths and facts. Third World Quarterly, 26(8), 1269-1284. doi: 10:1080/01436590500336757

Docquier, F., \& Rapoport, H. (2003). Ethnic discrimination and the migration of skilled labour. Journal of Development Economics, 70(1), 159-172. http://dx.doi.org/10.1016/S0304-3878(02)00081-0

Doomernik, J. (2013). Does Circular Migration Lead to "Guest Worker" Outcomes? International Migration, 51(1), 24-39. http://dx.doi.org/10.1111/j.1468-2435.2012.00744.x

Durand, J., Parrado, E. A., \& Massey, D. S. (1996). Migradollars and Development: A Reconsideration of the Mexican Case. International Migration Review, 30(2), 423-444. http://dx.doi.org/10.2307/2547388

Edwards, M. B. (2005). Migration in the Middle East and Mediterranean. A Regional Study prepared for the Global Commission on International Migration, Mediterranean Migration Observatory. Aristotelous 14, Kalithea, Athens 176-71: University Research Institute for Urban Environment and Human Resources, Panteion University.

Favell, A. (2008). The new face of East-West migration in Europe. Journal of Ethnic and Migration Studies, 34(5), 701-716. http://dx.doi.org/10.1080/13691830802105947

Fergany, N. (2001). Aspects of labour migration and unemployment in the Arab region. Egypt: Almishkat Centre for Research.

Ghosh, B. (2006). Migrants, remittances and development: Myths, rhetoric and realities. Geneva: International Organization for Migration (IOM).

Glytsos, N. P. (2002). The role of migrant remittances in development: Evidence from Mediterranean countries. International Migration, 40(1), 5-26. http://dx.doi.org/10.1111/1468-2435.00183

Griffin, K. (1998). Nine good reasons to love labour migration. Guest editorial, UC-MEXUS News, 35, Summer 1998: The University of California Institute for Mexico and the United States.

Hasan, R., Mitra, D., Ranjan, P., \& Ahsan, R. N. (2012). Trade liberalization and unemployment: Theory and evidence from India. Journal of Development Economics, 97(2), 269-280. http://dx.doi.org/10.1016/ j.jdeveco.2011.04.002

Hoang, L. A., Yeoh, B. S. A., \& Wattie, A. M. (2012). Transnational labour migration and the politics of care in the Southeast Asian family. Geoforum, 43(4), 733-740. http://dx.doi.org/10.1016/j.geoforum.2011.12.006 
Huang, S., \& Loa, I. (2009). Labour groups protest for better worker's rights. Taipei Times. Retrieved October 22, 2012, from_http://www.taipeitimes.com/News/taiwan/archives/2009/04/27/2003442132

Hugo, G. (2002). Effects of international migration on the family in Indonesia. Asia and Pacific Migration Journal, 11(1), 13-46.

Hui, W. T. (1997). Regionalization, economic restructuring and labour migration in Singapore. International Migration, 35(1), 109-130. http://dx.doi.org/10.1111/1468-2435.00006

Hull, J. R. (2007). Migration, Remittances and Monetization of Farm Labor in Subsistence Sending Areas. Asia and Pacific Migration Journal, 6(4), 451-484.

Ilahi, N., \& Jafarey, S. (1999). Guest worker migration, remittances and the extended family: Evidence from Pakistan. Journal of Development Economics, 58(2), 485-512. http://dx.doi.org/10.1016/S0304-3878(98) 00122-9

ILO. (2005). A global alliance against forced labour. Geneva: International Labour Organization (ILO).

ILO. (2008). Protecting migrant workers: Governance of labour migration in Asia and the Pacific. Bangkok, Thailand: Publication of the International Labour Office.

ILO. (2012). 21 Million People are now Victims of Forced labour, ILO says. Press release. Retrieved January 19, 2014, from http://www.ilo.org/global/about-the-ilo/newsroom/news/WCMS_181961/lang--en/index.htm

ILO. (2012). ILO Global Estimate of Forced Labour: Results and Methodology. Geneva: International Labour Office, $\mathrm{CH}-1211$.

Jampaklay, A., \& Kittisuksathit, P. (2009). Migrant worker's remittances: Cambodia, Lao PDR and Myanmar. Bangkok: ILO Regional Office for Asia and the Pacific.

Jones, H., \& Pardthaisong, T. (1999). The impact of overseas labour migration on rural Thailand: Regional, community and individual dimensions. Journal of Rural Studies, 15(1), 35-47. http://dx.doi.org/10.1016/ S0743-0167 (98)00052-7

Jones, R. C. (1998). Remittances and inequality: A question of migration stage and geographic scale. Economic Geography, 74(1), 8-25.

Jones, R. C. (2008). Introduction: The renewed role of remittances in the new world order. Economic Geography, 74(1), 1-7.

Kaneko, K. (2009). Foreign migrants in Taiwan and Japan: A comparative analysis. Asia Journal of Global Studies, 3(1), 22-36.

Kaur, A. (2009). Labour crossing in Southeast Asia: Linking historical and contemporary labour. New Zealand Journal of Asian Studies, 11(1), 276-303.

Kaur, A. (2010). Labour migration trends and policy challenges in Southeast Asia. Policy and Society, 29(4), 385-397. http://dx.doi.org/10.1016/j.polsoc.2010.09.001

Kesztenbaum, L. (2008). Cooperation and coordination among siblings: Brothers' migration in France, 1870-1940. The History of the Family, 13(1), 85-104. http://dx.doi.org/10.1016/j.hisfam.2008.01.006

Kim, J. (2012). Past and future of the labour force in emerging Asian economics. Japan and the World Economy, 24(2), 87-100. http://dx.doi.org/10.1016/j.japwor.2012.01.004

Korobkov, A. V., \& Zainochkovskaia, Z. A. (2004). The changes in the migration patterns in the post-Soviet states: The first decade. Communist and Post-Communist Studies, 37(4), 481-508.

Kwon, C. W., \& Chun, B. G. (2011). Relationship regarding the demand for labour between domestic temporary and foreign workers: Korean case. Japan and the World Economy, 23(1), 240-245.

Lee, J., \& Francisco, R. (2012). Human capital accumulation in emerging Asia, 1970-2030. Japan and World Economy, 24(2), 76-86. http://dx.doi.org/10.1016/j.japwor.2012.01.008

Lenard, P. T. (2012). Why Temporary Migration is not a Satisfactory Alternative to Permanent Migration. Journal of International Political Theory, 8(1-2), 172-183. doi: 10.3366/jipt.2012.0037.

León, J. D. (2013). The Efficacy and Impact of the Alien Transfer Exit Programme: Migrant Perspectives from Nogales, Sonora, Mexico. 15(2), 10-23.

Lindio-McGovern, L. (2004). Alienation and labour export in the context of globalization: Filipino migrant domestic workers in Taiwan and Hong Kong. Critical Asian Studies, 36(2), 217-238. 
Loveband, A. (2004). Positioning the protest: Indonesian migrant women workers in Taiwan. Journal of Contemporary Asia, 34(3), 336-348. http://dx.doi.org/10.1080/00472330480000141

Lowell, B. L., Teachman, J., \& Jing, Z. (1995). Unintended consequences of immigration reform: Discrimination and Hispanic employment. Demography, 32(4), 617-628. doi: 10.2307/2061678

Mahmoud, T. O., \& Trebesch, C. (2010). The economics of human trafficking and labour migration: Micro-evidence from Eastern Europe. Journal of Comparative Economics, 38(2), 173-188. http://dx.doi.org/10.1016/j.jce.2010.02.001

Manning, C. (2002). Structural change, economic crisis and international labour migration in East Asia. The World Economy, 25(4), 359-385. http://dx.doi.org/10.1111/1467-9701.00437

Martin, S. J., Jorgensen, N., \& Labeaga, J. M. (2007). The Volume and Geography of Remittances from the EU. European Commission.

Massey, D. J. (1988). Economic Development and International Migration in Comparative Perspective. Population and Development Review, 19(3), 431-446.

Massey, D. S., Arango, J., Hugo, G., Kouaouci, A., Pellegrino, A., \& Taylor, J. E. (1993). Theories of international migration: A review and appraisal. Population and Development Review, 19(3), 431-466.

McDougall, E., Natali, C., \& Tunon, M. (2011). Out-migration from Thailand: Policy, perspectives and challenges. In J. W. Huguet, \& A. Chamrarithirong (Eds.), Thailand Migration Report 2011. Migration for development in Thailand: Overview and tools for policymakers. Bangkok, Thailand: International Organization for Migration.

Moran-Taylor, M . (2008). Guatemala: migration and child rearing. Latin American Perspectives, 34(4), 79-95.

Mutersbaugh, T. (2002). Migration, common property, and communal labour: cultural politics and agency in a Mexican village. Political Geography, 21(4), 473-494. http://dx.doi.org/10.1016/S0962-6298(01)00081-6

O'Niel, K. (2004). Labour export as government policy: The case of the Philippines. Migration Information Source: Fresh Thought, Authoritative data, Global Reach. Retrieved October 22, 2012, from http://www.migrationinformation.org/Feature/display.cfm?ID=191

Reitz, J. G. (2001). Immigrant success in the knowledge economy: Institutional change and the immigrant experience in Canada, 1970-1995. Journal of Social Issues, 57(3), 579-613. http://dx.doi.org/10.1111/ $0022-4537.00230$

Remennick, L. (2013). Professional Identities in Transit: Factors Shaping Immigrant Labour Market Success. International Migration, 15(1), 152-168. http://dx.doi.org/10.1111/j.1468-2435.2011.00733.x

Richard, H., Adams, J. R., \& John, P. (2005). Do international migration and remittances reduce poverty in developing countries? World Development, 33(10), 1645-1669. http://dx.doi.org/10.1016/j.worlddev. 2005.05.004

Russell, S. S. (1986). Remittances from International Migration: A Review in Perspective. World Development, 14(6), 677-696. http://dx.doi.org/10.1016/0305-750X (86)90012-4

Shah, N. M. (2007). Migration to Kuwait: Trends, patterns and policies. Paper prepared for the migration and refuge movements in the Middle East and North Africa, The Forced Migration and Refugee Studies Program, 23-25 October: The American University in Cairo, Egypt.

Skeldon, R. (2008a). Migration and development. United Nations expert group meeting on International Migration and Development and Development in Asia and the Pacific, United Nations Economic and Social Commission for Asia and the Pacific, 20-21 September: Population Division, Department of Economic and Social Affairs, Bangkok, Thailand.

Skeldon, R. (2008b). International migration as a tool in development policy: A passing phase? Population and Development Review, 34(1), 1-18. http://dx.doi.org/10.1111/j.1728-4457.2008.00203.x

Sorensen, N. N., Hear, N. V., \& Pedersen, P. E. (2002). The migration-development nexus evidence and policy options. International Migration, 40(5), 260-287.

Tapinos, G. P. (2002). Globalization, regional integration, international migration. International Social Science Journal, 52(165), 297-306.

Taran, P., \& Geronimi, E. (2002). Globalization, labour and migration: Protection is paramount. Conferencia Hemisferica sobre Migracion Internacional: Derechos Humanosy Trata de Personas en las Americas, 
Santiago de Chile, 20-22 November, International Migration Programme: International Labour Office, Geneva.

Teitelbaum, M. S. (2008). The meanings and the futures of skilled migration. Canadian Diversity, 6(3), 26-29.

UNRTF. (2008). HIV/AIDS \&Mobility in South-East Asia. Bangkok: S. Asia Press (1989) Co., Ltd.

Wang, X., Huang, J., Zhang, L., \& Rozelle, S. (2011). The rise of migration and the fall of self employment in rural China's labour market. China Economic Review, 22(4), 573-584. http://dx.doi.org/10.1016/j.chieco. 2011.07.005

Weinberg, N. (2001). Mass migration and labour market incorporation: Soviet immigrants in Israel. Research in Social Stratification and Mobility, 18, 249-274.

Wells, J. (1996). Labour migration and international construction. Habitat Intl., 20(2), 296-306.

Wickarmasekara, P. (2000). Asian labour migration: Issues and challenges in an era of globalization. In Report and Conclusions: ILO Asia-Pacific Regional Symposium for Trade Union Organization on Migrant Workers, 6-8 December 1999, Kuala Lumpur, Malaysia, ILO. Bangkok, International Labour Office: Bureau of Workers Activities.

Xiang, B. (2007). How far are the left behind left behind? A preliminary study in rural China. Population, Space and Place, 13(3), 179-191. http://dx.doi.org/10.1002/psp.437

Yamanaka, K. (1993). New immigration and unskilled foreign workers in Japan. Pacific Affairs, 66(1), 72-90.

Yang, D. (2004). How remittances help migrant families. Migration Information Source: Fresh Thought, Authoritative data, Global Reach. Retrieved October 22, 2012, from http://www.migrationinformation.org/ USfocus/display.cfm?ID $=270$

Yeoh, B., Hoang, L. A., \& Lam, T. (2010). Human mobility, human development and human security: Effects of international migration on families left behind. National University of Singapore, Asian Meta Centre for Population and Sustainable Development Analysis: Civil Society Days, Global Forum on Migration and Development, Mexico.

Yiu, C. (2003). Foreign workers protest for better rights. Taipei Times. Retrieved October 22, 2012, from http://www.taipeitimes.com/News/front/archives/2003/12/29/2003085549

Yiu, C. (2005). Foreign workers protest. Taipei Times. Retrieved October 22, 2012 from http://www.taipeitimes.com/News/taiwan/archives/2005/01/13/2003219173

\section{Copyrights}

Copyright for this article is retained by the author(s), with first publication rights granted to the journal.

This is an open-access article distributed under the terms and conditions of the Creative Commons Attribution license (http://creativecommons.org/licenses/by/3.0/). 